NASA/TM-2002-211815

\title{
Surface Analysis and Tools
}

Kazuhisa Miyoshi

Glenn Research Center, Cleveland, Ohio 
Since its founding, NASA has been dedicated to the advancement of aeronautics and space science. The NASA Scientific and Technical Information (STI) Program Office plays a key part in helping NASA maintain this important role.

The NASA STI Program Office is operated by Langley Research Center, the Lead Center for NASA's scientific and technical information. The NASA STI Program Office provides access to the NASA STI Database, the largest collection of aeronautical and space science STI in the world. The Program Office is also NASA's institutional mechanism for disseminating the results of its research and development activities. These results are published by NASA in the NASA STI Report Series, which includes the following report types:

- $\quad$ TECHNICAL PUBLICATION. Reports of completed research or a major significant phase of research that present the results of NASA programs and include extensive data or theoretical analysis. Includes compilations of significant scientific and technical data and information deemed to be of continuing reference value. NASA's counterpart of peerreviewed formal professional papers but has less stringent limitations on manuscript length and extent of graphic presentations.

- TECHNICAL MEMORANDUM. Scientific and technical findings that are preliminary or of specialized interest, e.g., quick release reports, working papers, and bibliographies that contain minimal annotation. Does not contain extensive analysis.

- CONTRACTOR REPORT. Scientific and technical findings by NASA-sponsored contractors and grantees.
- CONFERENCE PUBLICATION. Collected papers from scientific and technical conferences, symposia, seminars, or other meetings sponsored or cosponsored by NASA.

- SPECIAL PUBLICATION. Scientific, technical, or historical information from NASA programs, projects, and missions, often concerned with subjects having substantial public interest.

- TECHNICAL TRANSLATION. Englishlanguage translations of foreign scientific and technical material pertinent to NASA's mission.

Specialized services that complement the STI Program Office's diverse offerings include creating custom thesauri, building customized data bases, organizing and publishing research results ... even providing videos.

For more information about the NASA STI Program Office, see the following:

- Access the NASA STI Program Home Page at http://www.sti.nasa.gov

- E-mail your question via the Internet to help@sti.nasa.gov

- Fax your question to the NASA Access Help Desk at 301-621-0134

- Telephone the NASA Access Help Desk at 301-621-0390

- Write to:

NASA Access Help Desk

NASA Center for AeroSpace Information 7121 Standard Drive

Hanover, MD 21076 
NASA/TM-2002-211815

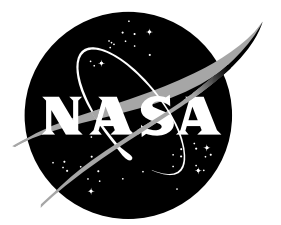

\section{Surface Analysis and Tools}

Kazuhisa Miyoshi

Glenn Research Center, Cleveland, Ohio

National Aeronautics and

Space Administration

Glenn Research Center 
Available from

NASA Center for Aerospace Information 7121 Standard Drive

Hanover, MD 21076
National Technical Information Service 5285 Port Royal Road Springfield, VA 22100

Available electronically at http://gltrs.grc.nasa.gov 


\title{
Surface Analysis and Tools
}

\author{
Kazuhisa Miyoshi \\ National Aeronautics and Space Administration \\ Glenn Research Center \\ Cleveland, Ohio 44135
}

\section{Introduction}

Many material properties are actually surface properties. For example, erosion, abrasion, wear, oxidation, corrosion, adhesion, bonding, friction, fatigue, and cracking are all affected by surface properties [1-3]. By modifying surfaces, depositing thin films, or producing multiple-layered coatings, the designer can enhance performance, such as resistance to erosion, abrasion, wear, oxidation, corrosion, and cracking, as well as biocompatibility or environmental compatibility [4-7].

In order to understand surface properties, and ultimately to provide better surfaces, it is necessary to study the physical and chemical characteristics of the material surface obtained by a given process. A number of tools are now available for surface analysis of any solid surface [8-10]. Because the surface plays such a crucial role in many processes, surface analysis and its tools have established their importance in a number of scientific, industrial, and commercial fields [11-21]. For example, the editors of Research \& Development Magazine surveyed the thin-film research community in August 2001 to determine the level of involvement with thin-film characterization tools and the immediate research concerns [22]. The survey indicated that thin films and coatings are commonly used in components and devices to improve mechanical properties, material performance, durability, strength, and resistance in basic industries, such as industrial coatings (21\% of researchers' responses), nanotechnology (19\%), optical components (19\%), plastics (17\%), ceramics (15\%), biomedical technology (10\%), instrumentation (10\%), microelectromechanical systems (10\%), and disk drives (6\%). Further, according to the survey, the most widely used tools for examining thin films and coatings are optical microscopy (60\%), scanning electron microscopy (56\%), energy-dispersive x-ray spectroscopy (29\%), Fourier transform infrared spectroscopy (29\%), surface profilometry (29\%), x-ray diffraction (27\%), Auger electron spectroscopy (25\%), ellipsometry (23\%), scanning probe microscopy (19\%), transmission electron microscopy (19\%), thermal analysis (15\%), x-ray photoelectron spectroscopy (12\%), confocal microscopy (10\%), and secondary ion mass spectroscopy (8\%).

Surface analysis is important for verifying the success of the surface preparation process including a coating process or surface treatment, for controlling the surface quality, and for identifying the surface contamination that can either enhance or inhibit the surface effects of the material. Selecting the proper analytical tool and method is crucial to obtaining the right information. To select the proper tool, the researcher must know the size of the specimen, the sampling area, the sampling depth, the spatial resolution, the detection sensitivity, whether quantitative or qualitative results and destructive or nondestructive analysis are desired, and many other factors. Each technique has its strengths and weaknesses. Therefore, no single tool can provide the answers to all problems. In many cases, it will be necessary to use multiple tools to reach an answer.

This chapter describes selected surface analytical tools that are being used in understanding phenomena and mechanisms of oxidation, adhesion, bonding, friction, erosion, abrasion, and wear and in defining the problems. The reader will find the basic principles and instrumentation details for a wide range of analytical tools in the literature [8-10, 19]. However, the analytical instrumentation field is moving rapidly, and within a year current spatial resolutions, sensitivities, imaging and mapping capabilities, accuracies, and instrument cost and size are likely to be out of date. Therefore, these references should be viewed with caution. 


\section{Nature of Surface Analysis}

A surface, by definition, is an interface, a marked discontinuity from one material to another. Because no change in nature is ever instantaneous, any real surface has a finite depth, and in characterizing a surface one must at some point consider just what this depth is.

The elemental and chemical state, phase, microstructure, crystalline structure, and defects of a solid often vary as a function of depth into the material or spatially across the material. Many tools specialize in addressing these variations down to extremely fine dimensions (on the order of angstroms in some cases). Requests are made for physical and chemical information as a function of depth to depths of $1 \mathrm{~mm}$ or so (materials have about 3 million atomic layers per millimeter of depth), as shown in fig. 1 . It is this region that affects a broad spectrum of physical, chemical, mechanical, and structural properties. Knowledge of these variations is of great importance to the selection and use of bulk materials, thin films, and modified surfaces.

Tables 1 to 3 briefly summarize the selected common tools available to surface engineers and tribologists today in studying the properties and behavior of solid surfaces. They give the commonly used tools, the information that can be obtained from the analysis, the vertical (depth) and the lateral (spatial) resolution that can be probed, and the form of the required specimen. For surfaces, interfaces, and thin films there is often little material to analyzehence, the presence of many microanalytical methods in tables 1 to 3 . Within microanalysis it is often necessary to identify trace components down to extremely low concentrations (parts per trillion in some cases), and a number of tools specialize in this aspect.

In other cases a high degree of accuracy in measuring the presence of major components might be the issue. Usually, the tools that are good for trace identification do not accurately quantify major components. Most complete analyses require the use of multiple analytical tools, the selection of which depends on the nature of the specimen and the desired information.

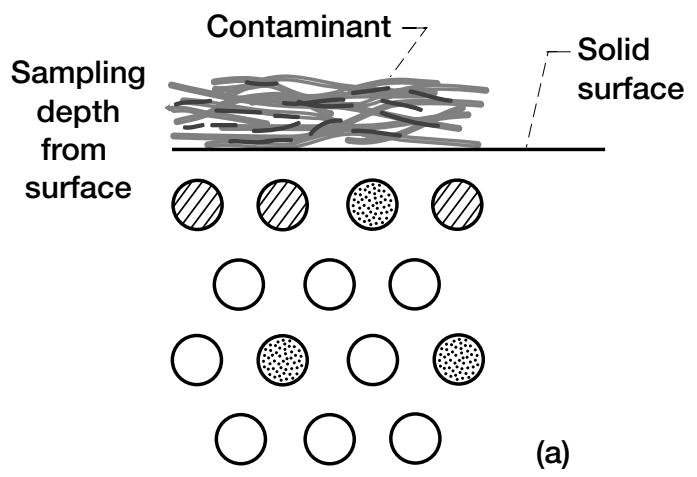

1 to $3 \mathrm{~nm}$

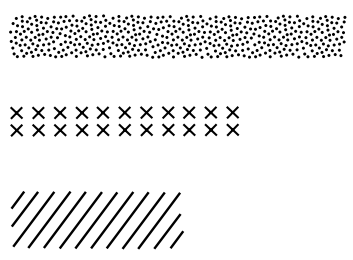

(b)

10 to $30 \mathrm{~nm}$
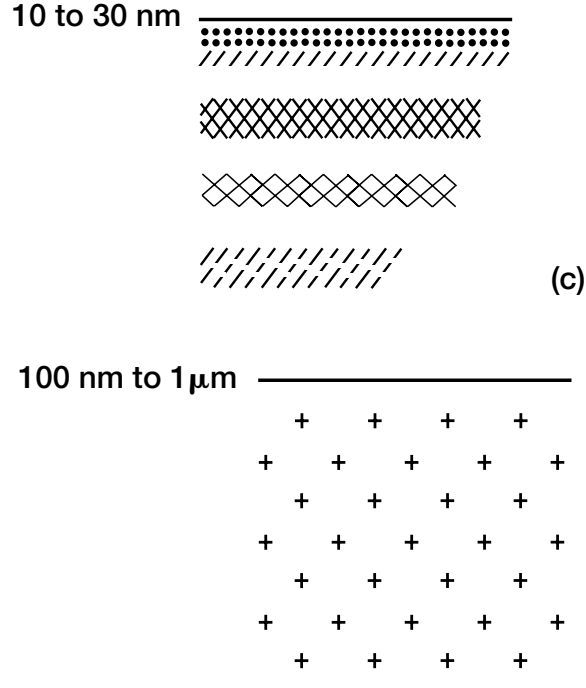

$1 \mathrm{~mm}$

Figure 1.-Schematic diagram showing regimes of (a) surface analysis, (b) thin-film analysis, (c) interface analysis, and (d) bulk substrate analysis. 


\section{Surface Chemistry}

Tools included in table 1 primarily provide elemental and chemical information on surfaces, interfaces, and thin films. The surface tools usually require a high vacuum. In most analyses the specimen is subjected to some kind of radiation beam: electrons, photons (light), ions, x rays, and neutral species. As a result of interactions between the solid surface and the incoming radiation, a beam of a similar (or a different) nature will emerge from the specimen. Measurement of the physical and/or chemical attributes of this emerging radiation will yield qualitative, and often quantitative, information about the chemistry, topography and morphology, and structure of the surface being probed.

TABLE 1.- SELECTED ANALYTICAL TOOLS FOR SURFACE CHEMISTRY

\begin{tabular}{|c|c|c|c|c|}
\hline Technique & Main information & $\begin{array}{l}\text { Vertical resolution } \\
\text { (depth probed) } \\
\text { (typical)* }\end{array}$ & $\begin{array}{c}\text { Lateral resolution } \\
\text { (typical) }\end{array}$ & $\begin{array}{c}\text { Types of solid } \\
\text { specimen } \\
\text { (typical) } \\
\end{array}$ \\
\hline $\begin{array}{l}\text { Auger electron } \\
\text { spectroscopy (AES) }\end{array}$ & $\begin{array}{l}\text { Elements (all except } \\
\text { hydrogen and helium) } \\
\text { Chemical state } \\
\text { Depth profiling } \\
\text { Image and mapping }\end{array}$ & $\begin{array}{l}0.5 \mathrm{~nm} \text { to several } \\
\text { nanometers }\end{array}$ & $\begin{array}{l}\text { A few tens of } \\
\text { nanometer or less }\end{array}$ & $\begin{array}{l}\text { Ultra-high- } \\
\text { vacuum- } \\
\text { compatible } \\
\text { solids }\end{array}$ \\
\hline $\begin{array}{l}\text { X-ray photoelectron } \\
\text { spectroscopy (XPS) }\end{array}$ & $\begin{array}{l}\text { Elements (all except } \\
\quad \text { hydrogen and helium) } \\
\text { Chemical state } \\
\text { Bonding } \\
\text { Organic compounds } \\
\text { Depth profiling } \\
\text { Imaging and mapping }\end{array}$ & $\begin{array}{l}0.5 \mathrm{~nm} \text { to several } \\
\text { nanometers }\end{array}$ & $5 \mu \mathrm{m}$ to $5 \mathrm{~mm}$ & $\begin{array}{l}\text { Ultra-high- } \\
\text { vacuum- } \\
\text { compatible } \\
\text { solids }\end{array}$ \\
\hline $\begin{array}{l}\text { Secondary ion mass } \\
\text { spectroscopy } \\
\text { (SIMS) }\end{array}$ & $\begin{array}{l}\text { Chemical state } \\
\text { Elements (hydrogen to } \\
\text { uranium) } \\
\text { Isotopes } \\
\text { Depth profiling } \\
\text { Imaging }\end{array}$ & $0.1 \mu \mathrm{m}$ to $1 \mu \mathrm{m}$ & $0.5 \mathrm{~nm}$ to $10 \mu \mathrm{m}$ & $\begin{array}{l}\text { All; vacuum- } \\
\text { compatible } \\
\text { solids }\end{array}$ \\
\hline $\begin{array}{l}\text { Rutherford } \\
\text { backscattering } \\
\text { spectrometry (RBS) }\end{array}$ & $\begin{array}{l}\text { Elements } \\
\text { Structure } \\
\text { Defects }\end{array}$ & $2 \mathrm{~nm}$ to $30 \mathrm{~nm}$ & $\begin{array}{l}1 \mathrm{~mm} \text { to } 4 \mathrm{~mm} ; 1 \mu \mathrm{m} \\
\text { in specialized case }\end{array}$ & $\begin{array}{l}\text { Ultra-high- } \\
\text { vacuum- } \\
\text { compatible } \\
\text { solids }\end{array}$ \\
\hline $\begin{array}{l}\text { Electron probe } \mathrm{x} \text {-ray } \\
\text { microanalysis } \\
\text { (EPMA) }\end{array}$ & $\begin{array}{l}\text { Elements (beryllium to the } \\
\text { actinides) } \\
\text { SEM imaging } \\
\text { Compositional mapping }\end{array}$ & $1 \mu \mathrm{m}$ & $0.5 \mu \mathrm{m}$ to $1 \mu \mathrm{m}$ & $\begin{array}{l}\text { All; vacuum- } \\
\text { compatible } \\
\text { solids }\end{array}$ \\
\hline $\begin{array}{l}\text { Energy-dispersive or } \\
\text { wavelength- } \\
\text { dispersive X-ray } \\
\text { spectroscopy (EDS } \\
\text { or WDS) }\end{array}$ & $\begin{array}{l}\text { Elements ( } Z \geq 5 \text {; boron to } \\
\text { uranium) } \\
\text { Spectroscopy } \\
\text { Imaging/mapping }\end{array}$ & $0.02 \mu \mathrm{m}$ to $1 \mu \mathrm{m}$ & $\begin{array}{l}0.5 \mu \mathrm{m} \text { to } 1 \mu \mathrm{m} \text { for } \\
\text { bulk specimens; as } \\
\text { small as } 1 \mathrm{~nm} \text { for thin } \\
\text { specimens }\end{array}$ & $\begin{array}{l}\text { All; vacuum- } \\
\text { compatible } \\
\text { solids }\end{array}$ \\
\hline $\begin{array}{l}\text { Fourier transform } \\
\text { infrared } \\
\text { spectroscopy (FTIR) }\end{array}$ & $\begin{array}{l}\text { Elements (all but not element } \\
\quad \text { specific) } \\
\text { Chemical bonds } \\
\text { Stress } \\
\text { Structure order } \\
\text { Defects } \\
\text { Imaging and mapping }\end{array}$ & $\begin{array}{l}10 \mathrm{~nm} \text { to } \\
\text { micrometers }\end{array}$ & $20 \mu \mathrm{m}$ to $5 \mathrm{~mm}$ & $\begin{array}{l}\text { All; solid, } \\
\text { liquid, or gas in } \\
\text { all forms }\end{array}$ \\
\hline Raman spectroscopy & $\begin{array}{l}\text { Identification of unknown } \\
\text { compounds } \\
\text { Elements (all but not element } \\
\quad \text { specific) } \\
\text { Chemical state } \\
\text { Bonding state } \\
\text { Structural order } \\
\text { Phase transitions }\end{array}$ & $\begin{array}{l}\text { Few micrometers } \\
\text { to millimeters }\end{array}$ & $1 \mu \mathrm{m}$ & $\begin{array}{l}\text { Solids, liquids, } \\
\text { gases, and thin } \\
\text { films }\end{array}$ \\
\hline
\end{tabular}


Auger electron spectroscopy (AES), x-ray photoelectron spectroscopy (XPS) or electron spectroscopy for chemical analysis (ESCA), secondary ion mass spectroscopy (SIMS), and Rutherford backscattering spectroscopy (RBS) have become the standard set of surface, thin-film, and interface analytical tools. Each has its own strengths and weaknesses and mostly they are complementary. AES and XPS each can determine the elemental composition (except for hydrogen and helium) and the chemical state of the outermost atomic layers of a surface [1, 2, 15-19]. SIMS can detect hydrogen and helium and has a much higher absolute sensitivity in many cases, but it seldom gives any chemical information and does not identify bonding characteristics as would XPS. SIMS, by its nature, has to remove material to do its analysis. RBS readily produces good quantitative results and does nondestructive depth profiling, but it lacks the absolute sensitivity of AES to many of the important elements and its depth resolution is not as good as AES can produce, in many cases.

AES and XPS both are surface-sensitive tools for probing the surface chemistry of solids. There are, however, a number of practical differences between the two tools (e.g., detection speed, background, and spatial resolution). XPS is more often selected to determine chemical information than is AES. The particular strengths of XPS are quantitative chemical state analysis and elemental analysis of surfaces (without standards). Although these techniques derive their usefulness from their intrinsic surface sensitivity, they can also be used to determine the composition of deeper layers. Such a determination is normally achieved through controlled surface erosion by ion bombardment. AES or XPS analyzes the residual surface left after a certain sputtering time with rare gas ions. In this way composition depth profiles can be obtained that provide a powerful means for analyzing worked layers, modified layers, thin films, multiple-layered coatings, lubricants, reaction film products, transferred films, and their interfaces. AES is generally more advantageous in composition depth profiling than is XPS.

AES - AES uses a focused electron beam to create secondary electrons near a solid surface. Some of these electrons (the Auger electrons) have the characteristic energies of the elements. AES has the attributes of high lateral resolution (10 $\mathrm{nm}$ with a field emission electron source) and an analysis depth to $10 \mathrm{~nm}$, relatively high sensitivity, and standardless semi-quantitative elemental analysis. In addition, some of the Auger electrons detected have energies characteristic, in many cases, of the chemical bonding of the atoms from which they are released. Because of their characteristic energies and the shallow depths from which they escape without energy loss, Auger electrons can characterize the elemental composition and, at times, the chemistry (chemical bonding information in some cases) of surfaces. The Auger peaks of many elements show significant changes in position or shape in different chemical conditions and environments. Further, the high spatial resolution of the electron beam and the sputter etching process allow microanalysis of three-dimensional regions of solid specimens.

A study of aluminum is an example of effective AES analysis. Figure 2(a) presents an AES spectrum of a chemically polished surface of a single-crystal aluminum pin specimen examined in ultrahigh vacuum $\left(10^{-9} \mathrm{~Pa}\right)$. A carbon contamination peak is evident as well as an oxygen contamination peak. Carbon and water are ubiquitous on any solid surface. Even a supposedly "clean" surface will show a significant carbon and water contribution to the AES spectrum because of the presence of one or more layers of adsorbed hydrocarbons. The surfaces of metals and ceramics usually contain, in addition to the constituent atoms, adsorbed films of water vapor, carbon monoxide and dioxide, and other oxide layers. A contaminant layer will attenuate the electron signal from the underlying surface and may mask important features in the spectrum. In fig. 2(a) the aluminum and oxygen peaks indicate that the surface was covered with aluminum oxide $\left(\mathrm{Al}_{2} \mathrm{O}_{3}\right)$ as well as a simple adsorbed oxygen film. In addition to the major AES peaks the chemically polished aluminum surface could contain small amounts of contaminant species, such as silicon and nitrogen.

In a vacuum environment sputtering with rare gas ions or heating can remove contaminants adsorbed on the surfaces of materials [23]. Figure 2(b) presents the AES spectrum taken after the aluminum pin specimen had been argon ion sputter cleaned. After the sputtering the contamination peaks became very small, and the relative peak intensity of aluminum increased markedly. Each contaminant was less than $1 \%$, on the order of typical AES trace capability. 

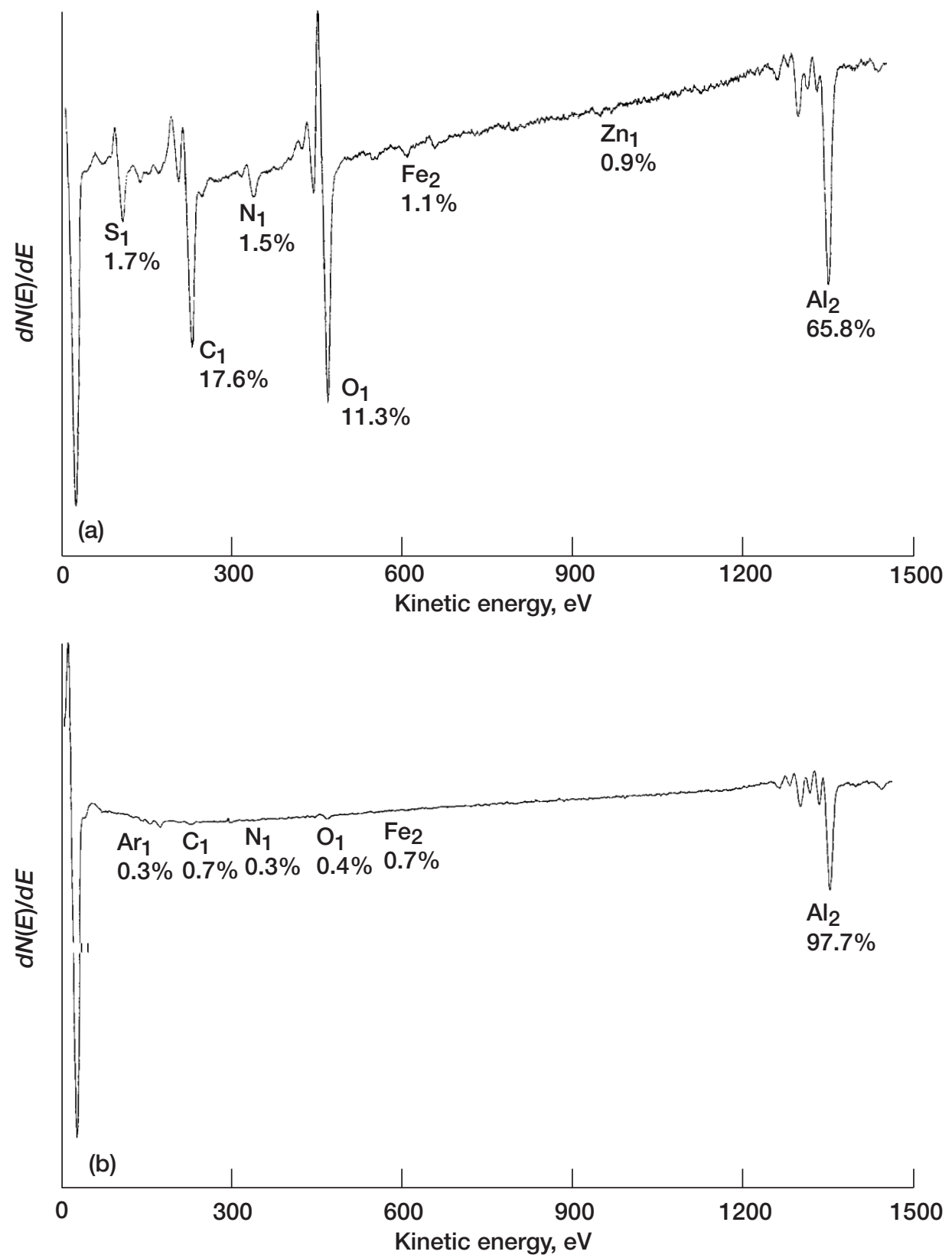

Figure 2.-AES spectra of single-crystal aluminum pin surfaces. (a) Chemically polished surface; 3-keV electron beam. (b) Argon-ion-sputter-cleaned surface; 3-keV electron beam.

Figure 3 presents the AES spectra of an as-received surface and an argon-ion-sputter-cleaned surface of a sapphire flat specimen. A carbon contamination peak is evident on the as-received sapphire surface. The cleaned sapphire surface consisted of $\mathrm{Al}_{2} \mathrm{O}_{3}$ and small amounts of carbon and implanted argon. The contaminants on the cleaned sapphire surface were on the order of typical AES trace capability.

When the contaminated surface of the chemically polished aluminum pin specimen was brought into contact with the argon-ion-sputter-cleaned surface of the sapphire flat specimen in ultrahigh vacuum, the pull-off forces (adhesion) required to separate the two surfaces in contact were small. The mean value and standard deviation of these pull-off forces were 231 and $241 \mu \mathrm{N}$ (fig. 4), respectively. On the other hand, 


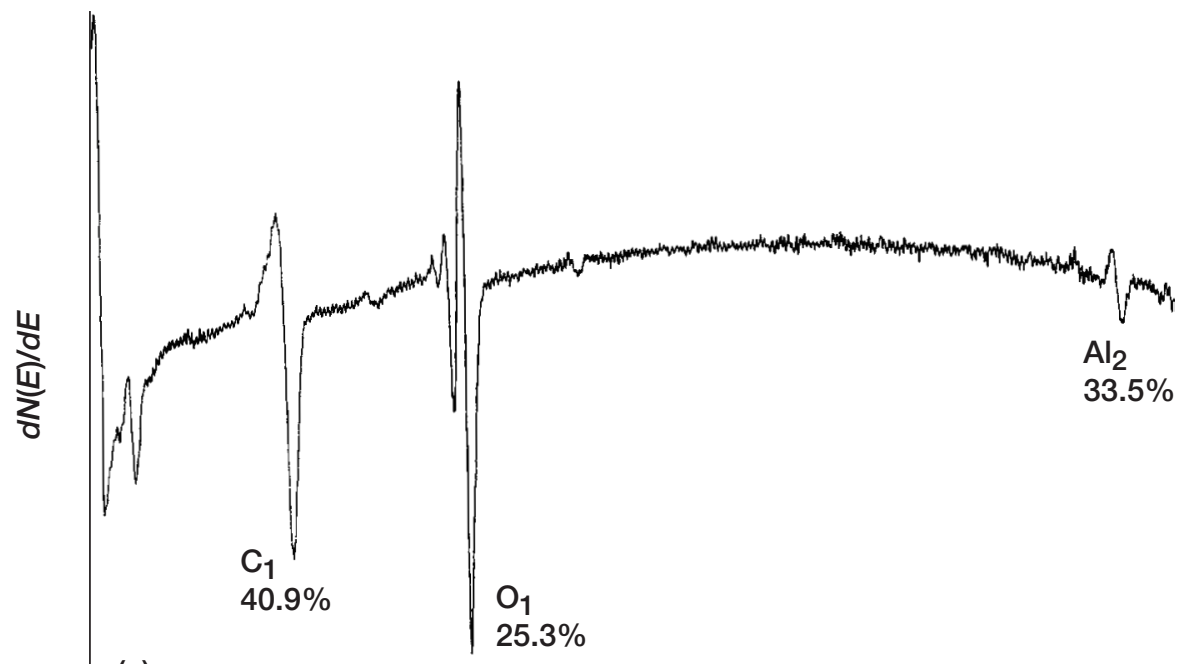

(a)
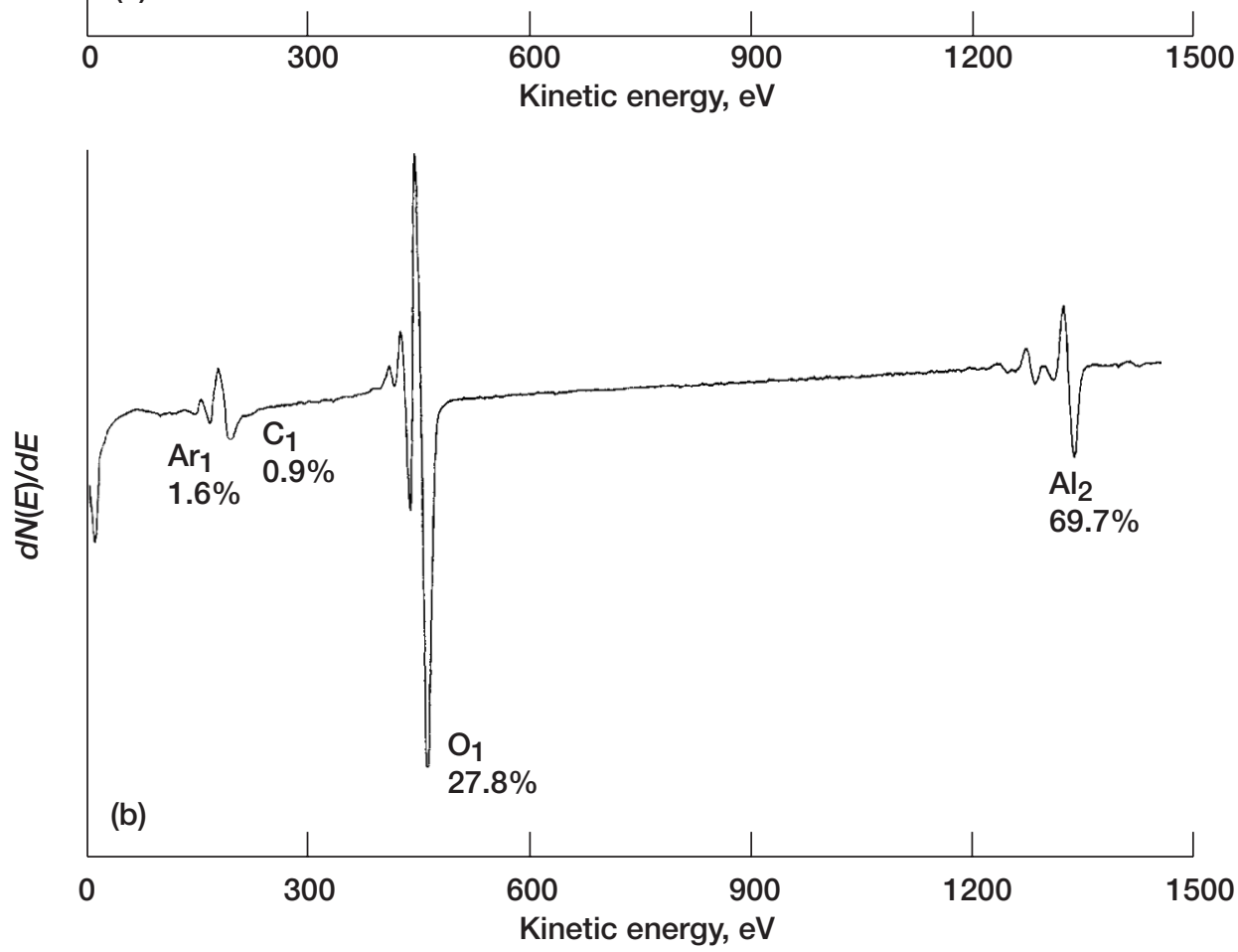

Figure 3.-AES spectra of single-crystal sapphire flat surfaces. (a) As-received surface; 2-keV electron beam. (b) Argon-ion-sputter-cleaned surface; 3-keV electron beam.

when the argon-ion-sputter-cleaned aluminum pin specimen was brought into contact with the argon-ionsputter-cleaned sapphire flat specimen in ultrahigh vacuum, strong bonds formed between the two materials. The mean value and standard deviation of the pull-off forces required to separate the two surfaces in contact were 3015 and $298 \mu \mathrm{N}$, respectively (fig. 4). The presence of a contaminant film on an aluminum surface reduced adhesion by a factor of 13 . Clearly, the importance of surface chemistry on the adhesion behavior of two solid surfaces in contact is demonstrated in the data of fig. 4.

XPS - In XPS monoenergetic soft x rays bombard a specimen material, causing electrons to be ejected. The elements present in the specimen can be identified directly from the kinetic energies of these ejected photoelectrons. Electron binding energies are sensitive to the chemical state of the atom. Although 


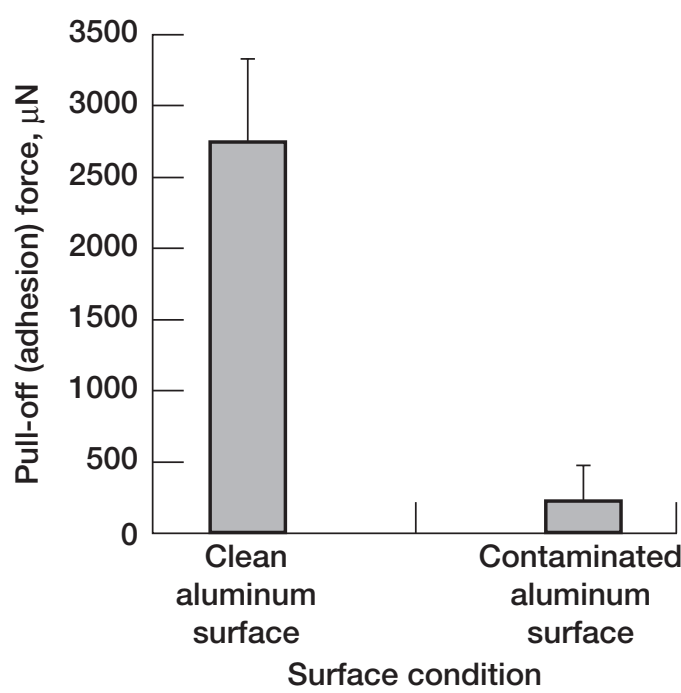

Figure 4.-Pull-off force (adhesion) for clean aluminum pin in contact with clean sapphire flat at normal load of $135 \mu \mathrm{N}$ and for contaminated aluminum pin in contact with clean sapphire flat at $1063 \mu \mathrm{N}$ in ultrahigh vacuum.
XPS is designed to deal with solids, specimens can be gaseous, liquid, or solid. XPS is applicable to metals, ceramics, semiconductors, and organic, biological, and polymeric materials. Although x-ray beam damage can sometimes be significant, especially in organic materials, XPS is the least destructive of all the electron or ion spectroscopy methods. The depth of solid material probed by XPS varies from the top 2 atomic layers to 15 to 20 layers (an analysis depth to 0.5 to $5 \mathrm{~nm}$ ). XPS has the lateral resolution of $5 \mathrm{~mm}$ to $75 \mu \mathrm{m}(5 \mu \mathrm{m}$ in special instruments). This surface sensitivity, combined with quantitative and chemical analysis capabilities, has made XPS the most broadly applicable general surface analysis tool used today, especially in the field of surface engineering and tribology. The main advantage of XPS is its ability to provide chemical information from the shifts in binding energy.

One classic study of single-crystal silicon carbide $(\mathrm{SiC})$ heat treated at $1500{ }^{\circ} \mathrm{C}$ in vacuum is an example of effective XPS analysis [23, 24]. In the study in situ XPS analyses were conducted with the heat-treated

$\mathrm{SiC}$. Also, single-pass sliding experiments were conducted with the heat-treated $\mathrm{SiC}$ in contact with iron at various temperatures from room temperature to $1200{ }^{\circ} \mathrm{C}$ in ultrahigh vacuum. As depicted in fig. 5 the XPS spectra of the heat-treated SiC surface indicate distinguishable kinds of carbon (i.e., a large graphite peak and a small carbide peak associated with the $\mathrm{SiC}$ as a result of the chemical shifts). XPS analysis revealed that, concurrently, graphitic carbon replaced carbidic carbon at the topmost layers of
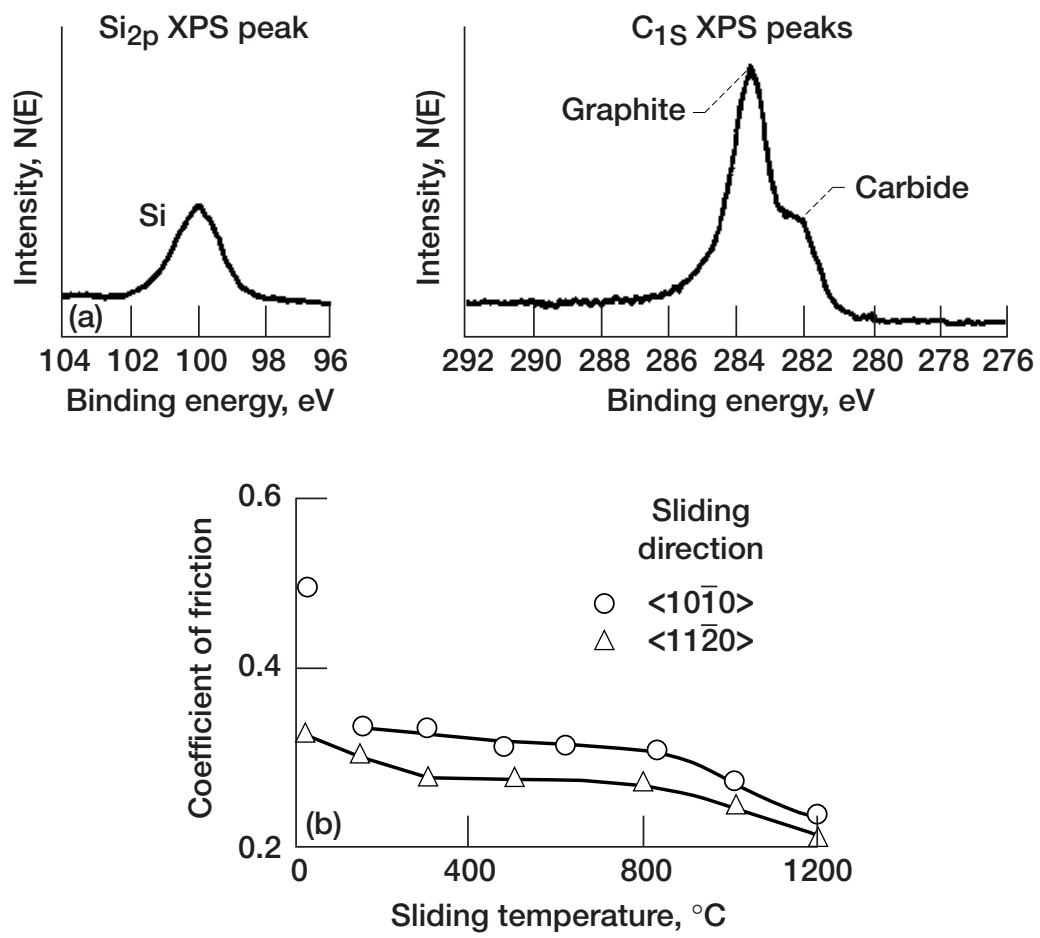

Figure 5.-XPS spectra of silicon carbide surface heat-treated to $1500{ }^{\circ} \mathrm{C}$ and measured coefficients of friction on that surface to $1200^{\circ} \mathrm{C}$ after heat treatment. 
$\mathrm{SiC}$, as a result of the evaporation of silicon. The outermost surficial graphite layer on the $\mathrm{SiC}$ heat treated at $1500{ }^{\circ} \mathrm{C}$ was 1.5 to $2.4 \mathrm{~nm}$ in depth. The coefficients of friction for the graphitized $\mathrm{SiC}$ in vacuum were generally low. The heat-treated $\mathrm{SiC}$ had lower coefficients of friction, by more than onehalf, than those for nongraphitized, clean $\mathrm{SiC}$ surfaces. The coefficient of friction dropped from 0.8 for the nongraphitized, clean $\mathrm{SiC}$ surfaces to 0.2 for the graphitized surfaces. Note that the carbide peak obtained from the nongraphitized, clean SiC surface dominated in the XPS spectrum. Thus, this study demonstrated that heat treatment of $\mathrm{SiC}$ at $1500{ }^{\circ} \mathrm{C}$ converted the surface exhibiting high friction to low friction and identified the surface chemical changes responsible for the friction behavior. The results of fig. 5 illustrate the value of surface analytical approaches in friction investigations [23, 25].

\section{Topography and Morphology}

Surface imaging analyses (e.g., table 2) are important for assessing the preparation process, phase, damage, defects, or morphological characteristics of solid surfaces. They provide a visual feel for the surface of a device and can quickly identify problem areas. Observation and topography measurement of the physical attributes will yield qualitative, and often quantitative, information about the morphology of the surface being probed. Scanning electron microscopy (SEM), optical interferometry (optical profilometry), and atomic force microscopy (AFM) have become the standard set of imaging analytical tools. Each has its own strengths and mostly they are complementary.

SEM-SEM is an excellent first-look analytical tool when conventional light microscopy no longer provides adequate spatial resolution or depth of focus. SEM is the most common surface imaging tool to materials engineers, surface engineers, and tribologists interested in studying the morphology, defects, fractures, erosion, and wear of material surfaces.

In SEM an electron beam is focused into a fine probe and subsequently raster scanned over a small rectangular area. As the electron beam interacts with the specimen, it creates various signals, such as secondary electrons, internal currents, and photon emissions, all of which can be collected by appropriate detectors. The use of electron microprobe tools in SEM is now a well-established procedure. Especially, the combination of SEM and x-ray analysis utilizing either energy-dispersive x-ray spectroscopy (EDS) or wavelength-dispersive x-ray spectroscopy (WDS) provides a powerful tool for local microanalysis. SEM-EDS or SEM-WDS produces three principal images: secondary electron images, backscattered electron images, and elemental x-ray energy maps or x-ray energy histograms. Secondary electrons carry information about surface topography and morphology. Backscattered primary electrons carry information about atomic number and topographic contrast. X-rays carry information about elemental composition and an element's concentration distribution. Three modes of analysis are commonly used: spectrum acquisition, spatial distribution or dot-mapping of the elements, and element line scans. X-rays are generated over a larger volume than are either the backscattered or secondary electrons detected. Thus, the spatial resolution of $\mathrm{x}$-ray maps $(0.5$ to $1 \mu \mathrm{m})$ is much larger than that of secondary electron images $(\sim 1.5 \mathrm{~nm}$ with a field emission electron source) or backscattered electron images.

One example of SEM-EDS analysis is a study of titanium- $6 \%$ aluminum-4\% vanadium (Ti-6Al-4V) in vacuum. In the study multiple-pass sliding friction experiments were conducted with the Ti-6Al-4V in contact with a typical nickel-base superalloy in vacuum at room temperature. Substantial plastic deformation and severe surface damage occurred on the Ti-6Al-4V surface when sliding against the superalloy in vacuum [26]. Figure 6 presents a secondary electron SEM image, a backscattered electron SEM image, and an x-ray energy histogram of the wear surface produced on the superalloy after 100 passes at a load of $2.5 \mathrm{~N}$. Figure 6 shows a Ti-6Al-4V patch on the wear track of the superalloy surface. The interfacial bonds (adhesion) between the two materials in contact in vacuum are generally strong, and seizure between the two contacting materials can occur. Seizure (or galling) increased the coefficient of friction to 1.4. Failure of Ti-6Al-4V generally occurs either in tension or in shear because some of the interfacial 
TABLE 2.- SELECTED IMAGING ANALYTICAL TOOLS FOR TOPOGRAPHY AND MORPHOLOGY

\begin{tabular}{|c|c|c|c|c|}
\hline Technique & $\begin{array}{c}\text { Main information } \\
\text { obtained }\end{array}$ & $\begin{array}{l}\text { Vertical resolution (depth } \\
\text { probed) (typical)* }\end{array}$ & Lateral resolution (typical) & $\begin{array}{l}\text { Types of solid } \\
\text { specimen } \\
\text { (typical) }\end{array}$ \\
\hline $\begin{array}{l}\text { Scanning } \\
\text { electron } \\
\text { microscopy } \\
\text { (SEM) }\end{array}$ & $\begin{array}{l}\text { Imaging } \\
\text { Morphology } \\
\text { Elements } \\
\text { Damages } \\
\text { Defects } \\
\text { Crystallography } \\
\text { Grain structure } \\
\text { Magnetic domains }\end{array}$ & $\begin{array}{l}\text { Variable from a few } \\
\text { nanometers to a few } \\
\text { micrometers }\end{array}$ & $\begin{array}{l}1 \text { to } 50 \mathrm{~nm} \text { in secondary } \\
\text { electron mode }\end{array}$ & $\begin{array}{l}\text { Conductors and } \\
\text { coated insulators }\end{array}$ \\
\hline $\begin{array}{l}\text { Optical profiler } \\
\text { and laser } \\
\text { interferometry }\end{array}$ & $\begin{array}{l}\text { 3D and 2D imaging } \\
\text { Morphology } \\
\text { Profilometry } \\
\text { Topography } \\
\text { Film thickness } \\
\text { Wear volume } \\
\text { Scar and crater depth } \\
\text { Surface defects }\end{array}$ & $\sim 0.1 \mathrm{~nm}$ & $\begin{array}{l}\text { A few submicrometers to a } \\
\text { few tens of micrometers }\end{array}$ & $\begin{array}{l}\text { All but } \\
\text { transparent films } \\
\text { and materials }\end{array}$ \\
\hline $\begin{array}{l}\text { Atomic force } \\
\text { microscopy } \\
\text { (AFM) or } \\
\text { scanning force } \\
\text { microscopy } \\
\text { (SFM) }\end{array}$ & $\begin{array}{l}\text { Topography } \\
\text { Friction force mapping } \\
\text { Morphology } \\
\text { Profilometry } \\
\text { Film thickness } \\
\text { Wear volume } \\
\text { Scar and crater depth } \\
\text { Structure } \\
\text { Surface defects }\end{array}$ & $<0.03 \mathrm{~nm}$ to $0.05 \mathrm{~nm}$ & Atomic to $1 \mathrm{~nm}$ & All \\
\hline $\begin{array}{l}\text { Stylus } \\
\text { profilometry }\end{array}$ & $\begin{array}{l}\text { Profilometry } \\
\text { Topography } \\
\text { Film thickness } \\
\text { Morphology } \\
\text { Scar and crater depth } \\
\text { Wear volume } \\
\text { Surface defects }\end{array}$ & $0.5 \mathrm{~nm}$ & $100 \mathrm{~nm}$ & $\begin{array}{l}\text { Almost all; } \\
\text { flat smooth films }\end{array}$ \\
\hline $\begin{array}{l}\text { Confocal } \\
\text { microscopy }\end{array}$ & $\begin{array}{l}\text { 3D and 2D imaging } \\
\text { Morphology } \\
\text { Profilometry } \\
\text { Topography } \\
\text { Film thickness } \\
\text { Wear volume } \\
\text { Scar and crater depth } \\
\text { Surface defects } \\
\text { Live cells }\end{array}$ & $\begin{array}{l}\text { Variable from a few } \\
\text { nanometers to a few } \\
\text { micrometers }\end{array}$ & $\begin{array}{l}\text { Variable; optical, } 0.5 \mu \mathrm{m} \text { to } \\
4 \mu \mathrm{m} ; \mathrm{SEM}, 1 \mu \mathrm{m} \text { to } \\
50 \mu \mathrm{m}\end{array}$ & Almost all \\
\hline $\begin{array}{l}\text { Transmission } \\
\text { electron } \\
\text { microscopy } \\
\text { (TEM) }\end{array}$ & $\begin{array}{l}\text { Atomic structure } \\
\text { Microstructure } \\
\text { Crystallography defects } \\
\text { Imaging and mapping } \\
\text { Morphology }\end{array}$ & None & $\leq 0.2 \mathrm{~nm}$ & $\begin{array}{l}\text { Conductors, } \\
\text { semiconductors, } \\
\text { coated insulators }\end{array}$ \\
\hline $\begin{array}{l}\text { Light } \\
\text { microscopy } \\
\text { (general) }\end{array}$ & $\begin{array}{l}\text { Imaging } \\
\text { Morphology } \\
\text { Damages } \\
\text { Defects } \\
\text { Phase } \\
\text { Magnetic flux and field }\end{array}$ & Variable & Variable & All \\
\hline
\end{tabular}

* The vertical resolution is a measurement of the technique's ability to clearly distinguish a property as a function of depth. 

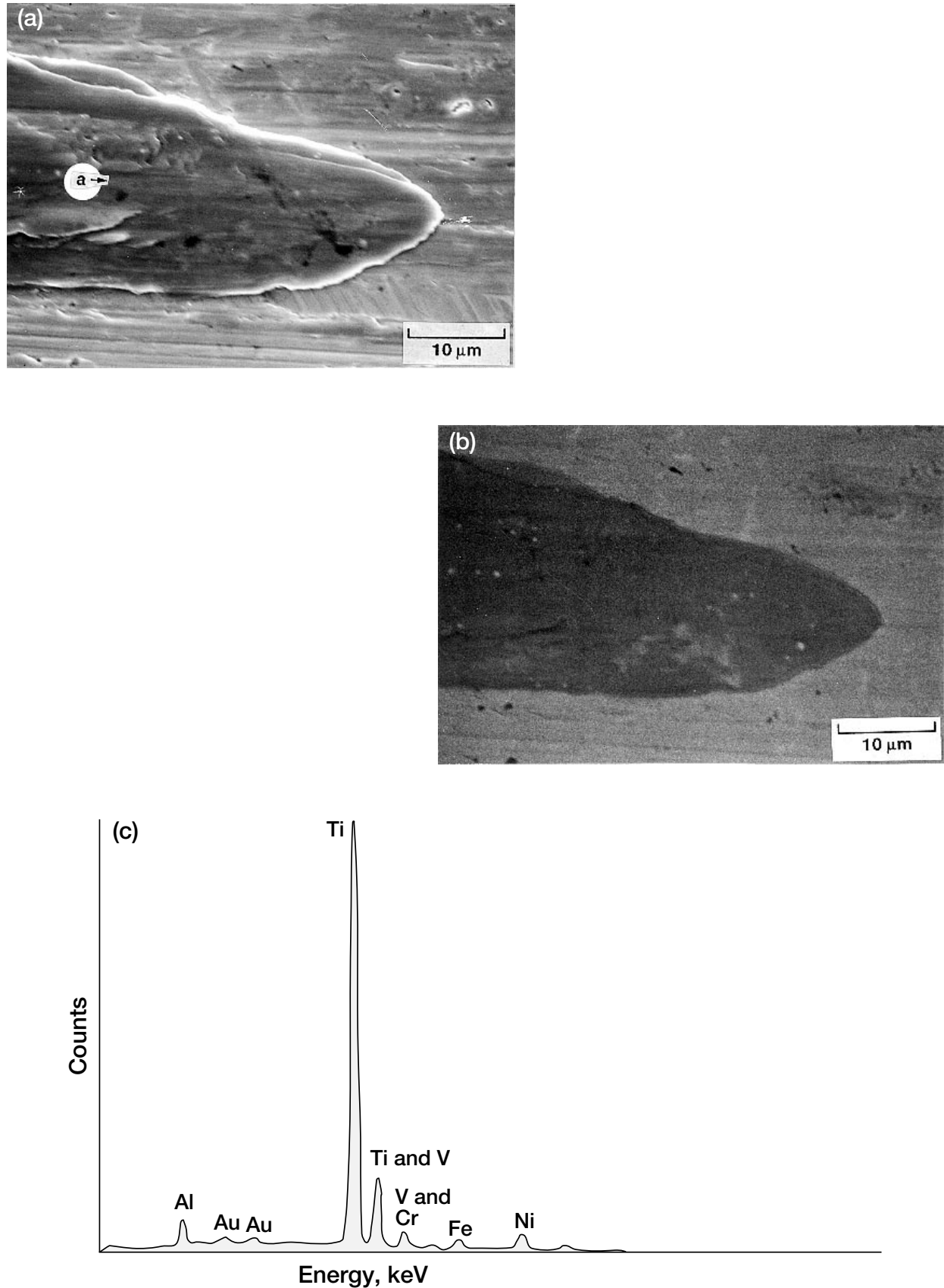

Figure 6.-Large transferred patch of Ti-6Al-4V on nickel-base superalloy disk specimen after sliding by Ti-6Al-4V pin specimen at $2.5 \mathrm{~N}$ in vacuum, showing transfer patches of Ti-6Al-4V. (a) Secondary electron SEM image. (b) Backscattered electron SEM image. (c) EDS spectrum of transferred film on disk. (Data taken at point indicated in part (a). Thin gold film used to reduce charging of mount is responsible for gold signal in spectrum.) 
bonds are generally stronger than the cohesive bonds within the cohesively weaker Ti-6Al-4V. The failed Ti-6Al-4V subsequently transfers Ti-6Al-4V patches to the contacting superalloy surface. The transfer patches shown in fig. 6 occupied a large area fraction of the overall wear track. Thus, severe damage, often called scuffing, scoring, or galling, occurred in the unlubricated contact between the Ti-6Al-4V and the nickel-base superalloy superalloy in vacuum. The results illustrate the value of the SEM and EDS surface analytical approaches in seizure (galling) and wear investigations.

Optical interferometry - Optical interferometry is a useful tool available today to surface engineers and tribologists interested in studying surface topography. Optical interferometry (also called an optical profiler; a non-contact, vertical-scanning, white-light interferometer; or a non-contact, vertical-scanning, laser interferometer) can profile an extremely wide range of surface heights and can measure surface features without contact [27]. It characterizes and quantifies surface roughness, step height, bearing ratio, height distribution, critical dimensions such as area and volume of damage, eroded craters, wear scars, and other topographical features. It has three-dimensional profiling capability with excellent precision and accuracy; for example, profile heights ranging from $<1 \mathrm{~nm}$ to $5000 \mu \mathrm{m}$ at speeds to $10 \mu \mathrm{m} / \mathrm{sec}$ with $0.1-\mathrm{nm}$ height resolution and large profile areas to $50 \mathrm{~mm}$ by $50 \mathrm{~mm}$ or $100 \mathrm{~mm}$ by $100 \mathrm{~mm}$.

In optical interferometry light reflected from the surface of interest interferes with light from an optically flat reference surface. Deviations in the fringe pattern of bright and dark lines produced by the interference are related to differences in surface height. If an imaging array is used, three-dimensional information can be provided. In general, optical profilers have some advantages-non-destructive measurement, no specimen preparation, and short analysis time under ambient conditions-but also some disadvantages. If the surface is too rough (roughness greater than $1.5 \mathrm{~mm}$ ), the interference fringes can be scattered to the extent that topography cannot be determined. If more than one matrix is involved (e.g., multiple thin films on a substrate) or if the specimen is partially or totally transparent to the wavelength of the measurement system, measurement errors can be introduced. Multiple-matrix specimens can be measured if coated with a layer that is not transparent to the wavelength of light used.

The shape of a surface can be displayed by a computer-generated map developed from digital data derived from a three-dimensional interferogram of the surface. Computer processing and frequency domain analysis result in a quantitative three-dimensional image. Such a map shows details of individual features and also the general topography over an area and describes surfaces. For example, fig. 7(a) shows a three-dimensional view of an optical interferometry image taken at the beginning of a wear track (groove) produced on a gamma titanium aluminide flat (Ti-48Al-2Cr-2Nb in atomic percent) with a rounded diamond pin (a Rockwell cone diamond with a tip radius of $0.2 \mathrm{~mm}$ ) in air at room temperature. In the experiment the surfaces of the Ti-48Al-2Cr-2Nb flat and the diamond pin were brought into contact and loaded at $100 \mathrm{~N}$, and the single-pass sliding was begun at a sliding velocity of $12 \mathrm{~mm} / \mathrm{min}$. Clearly, a plastically deformed permanent groove was formed on the Ti-48Al-2Cr-2Nb surface where the diamond began to slide. The plastically deformed Ti-48Al-2Cr-2Nb was subsequently piled onto the sides of the groove. The quantitative volume, height, and depth of the displaced Ti-48Al-2Cr-2Nb were directly processed by the computer. In the view of this particular groove the volume and the maximum height, calculated from the three-dimensional image, of the piled Ti-48Al-2Cr-2Nb on the sides of groove were $1.64 \times 10^{6} \mu \mathrm{m}^{3}$ and $30.81 \mu \mathrm{m}$, respectively, whereas the volume loss and the groove depth were $1.63 \times 10^{6} \mu \mathrm{m}^{3}$ and $42.94 \mu \mathrm{m}$, respectively. The sliding action also produced cracks, which generally propagate perpendicular to the sliding direction. The combination of data taken from optical profilometry and scanning electron microscopy (SEM) verified that the cracks did propagate perpendicular to the sliding direction. The Ti-48Al-2Cr-2 $\mathrm{Nb}$ failed either in tension or in shear.

Another study was done of a polymer matrix composite (PMC). Erosion tests were conducted with the PMC in an air-sand erosion rig. Substantial erosion occurred on the PMC surface. Figure 7(b), as an example, shows a three-dimensional view of an optical interferometry image of an erosion crater for PMC (vane specimen) eroded at an impact angle of $20^{\circ}$ by using $15 \mathrm{~g}$ of Arizona road dust as the erodent. In this particular case the volume loss and maximum depth, calculated from the three-dimensional image, of the eroded crater were $3.00 \times 10^{10} \mu \mathrm{m}^{3}$ and $69.42 \mu \mathrm{m}$, respectively. 

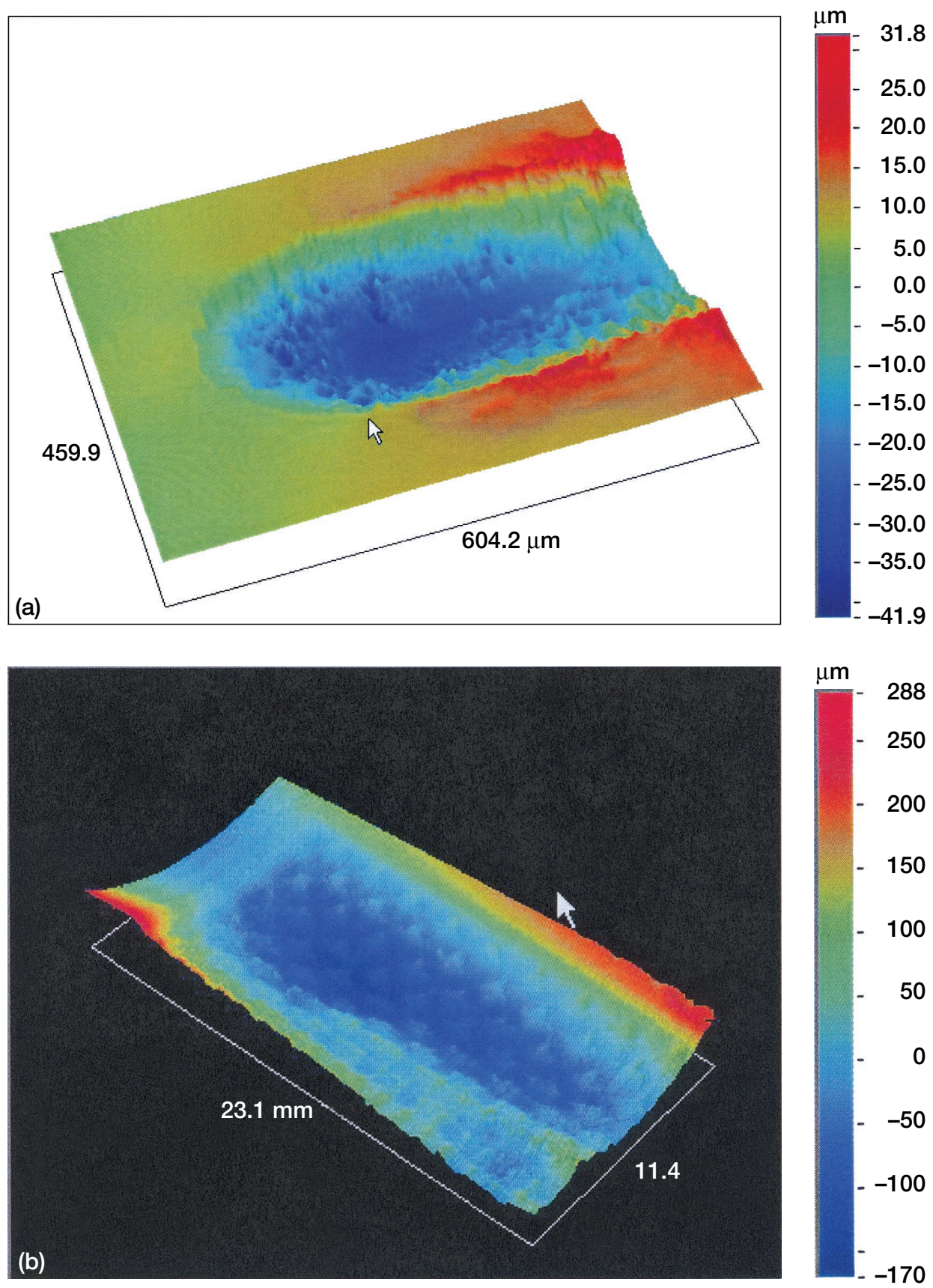

Figure 7.-Optical interferometry images. (a) Three-dimensional view of wear track (groove) produced on gamma titanium aluminide (Ti-48Al-2Cr-2Nb in atomic percent) flat surface with rounded diamond (Rockwell cone diamond with tip radius of $0.2 \mathrm{~mm}$ ) in air. Volume of material grooved, $1.63 \times 10^{6} \mu \mathrm{m}^{3}$; depth of groove, $42.94 \mu \mathrm{m}$.

(b) Erosion crater produced on polymer matrix composite vane specimen. Volume loss of material eroded, $3.00 \times 10^{10} \mu \mathrm{m}^{3}$; depth of eroded crater, $69.42 \mu \mathrm{m}$. 
The results of the studies shown in fig. 7 demonstrated that optical interferometry can be a powerful analytical tool for measuring critical dimensions, such as the volume, depth, and area of the wear scar and eroded crater, respectively.

AFM-One popular variant of scanning probe microscopy is atomic force microscopy (AFM), also called scanning force microscopy (SFM). AFM can measure the force of interaction between a specimen surface and a sharp probe tip [28]. The tip, a couple of micrometers long and often less than $10 \mathrm{~nm}$ in diameter, is located at the free end of a cantilever $100 \mathrm{~mm}$ to $200 \mathrm{~mm}$ long. When the tip comes within a few angstroms of the specimen surface, repulsive van der Waals forces between the atoms on the tip and those on the specimen cause the cantilever to deflect, or bend. A detector, such as the position-sensitive photodetector, measures the cantilever deflection as the tip is scanned over the specimen or the specimen is scanned under the tip. As a piezoelectric scanner gently traces the tip across the specimen (or the specimen under the tip), the contact force causes the cantilever to bend to accommodate changes in topography. The measured cantilever deflections allow a computer to generate a map of surface topography. Atomic force microscopes can be used to study insulating and semiconducting materials as well as electrical conducting materials. Most atomic force microscopes currently used detect the position of the cantilever with optical techniques. The position-sensitive photodetector itself can measure light displacements as small as $1 \mathrm{~nm}$. The ratio of the path length between cantilever and detector to the length of the cantilever itself produces a mechanical amplification. As a result the system can detect even 0.1-nm vertical movements of the cantilever tip. Other methods of detecting cantilever deflection rely on optical interference, a scanning tunneling microscope tip, or piezoresistive detection (fabricating the cantilever from a piezoresistive material). In addition to having higher spatial resolution than SEM, AFM requires little or no sample preparation and can analyze specimens in ambient or even hydrated conditions.

The shape of a surface can be displayed by a computer-generated map developed from digital data derived from many closely spaced parallel profiles taken by this process. Such a map shows details of individual features and also the general topography over an area and describes surfaces. Many engineering surfaces have height distributions that are approximately Gaussian (i.e., they can be described by the normal probability function). It is also useful to describe surfaces in terms of the integral of the distribution (bearing ratio), which gives the fraction of the surface at or below each height. The well-known Abbott's bearing curve, which gives the contact area that would exist if the hills were worn down to the given height by an ideally flat body, is the fraction of the surface at or above each height. Many modern surface analyzers provide chart or video displays of height histogram and bearing ratio (Abbott's bearing curve or bearing area curve) as standard features [29]. Figure 8 gives examples of AFM images of an ion-beam-deposited, diamondlike carbon (DLC) film and a chemical-vapor-deposited (CVD), fine-grain diamond film, both deposited on mirror-polished silicon substrates (DLC on silicon and CVD diamond on silicon). The DLC film surface has a smooth, flat morphology. The CVD diamond surface has a granulated or spherulitic morphology: the surface contains spherical asperities of different sizes [30]. The surface roughness of the DLC on silicon is $0.49 \mathrm{~nm}$ root-mean-square (rms), and the surface roughness of the CVD diamond on silicon is $58.8 \mathrm{~nm}$ rms. Also, figs. 8(a) and (b) show actual three-dimensional height profiles, histograms, and bearing ratios for the DLC on silicon and the CVD diamond on silicon, respectively.

\section{Structure and Crystallography}

Three tools included in table 3 all have diffraction in their names and give long-range order information on atomic positions from diffraction patterns. They are nondestructive techniques because of the specimen preparation methods. Their role is to provide structural information on surfaces, interfaces, and thin films. Low-energy electron diffraction (LEED) and reflection high-energy electron diffraction (RHEED) use electrons in high vacuum, whereas $\mathrm{x}$-ray diffraction (XRD) uses $\mathrm{x}$ rays in most environments. LEED and RHEED are surface sensitive and provide surface crystallographic information, 


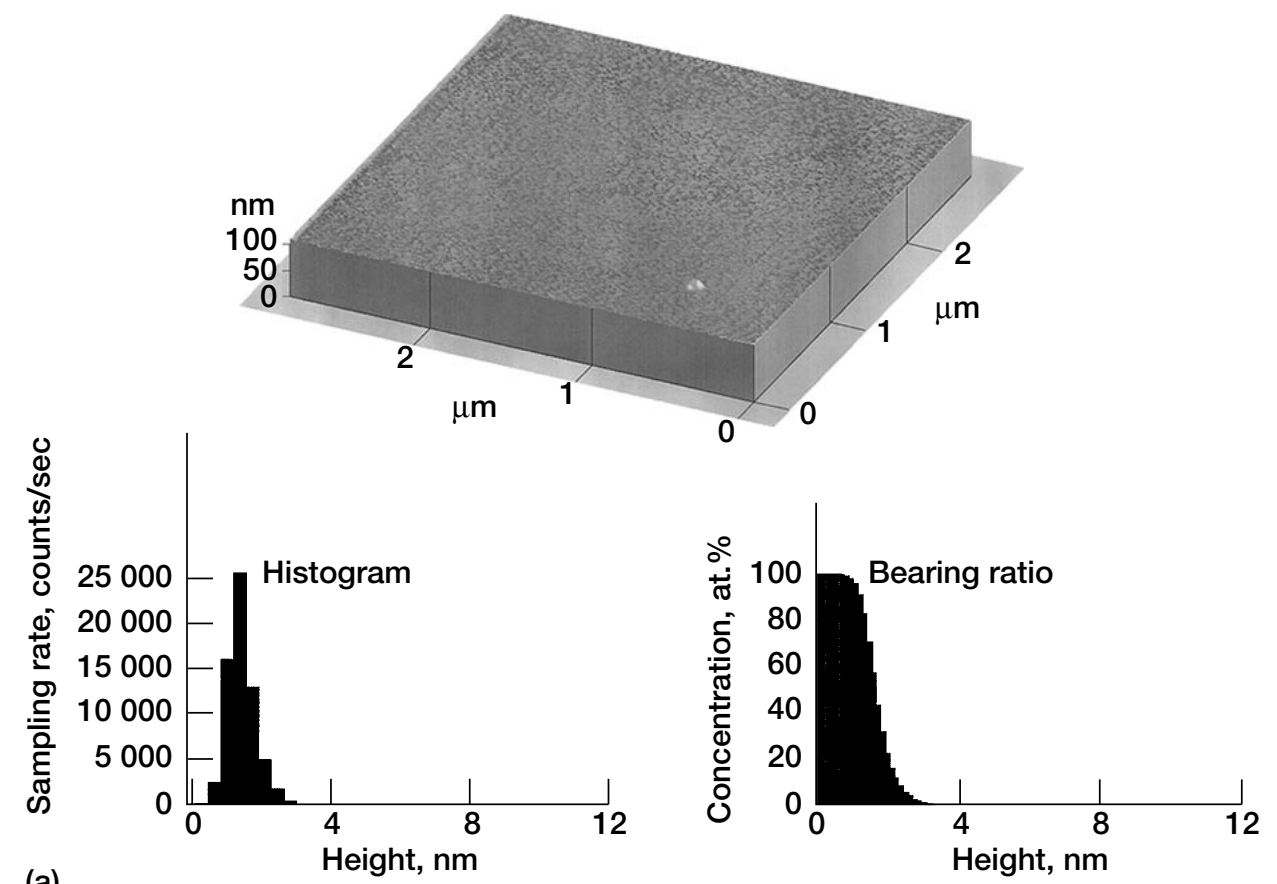

(a)
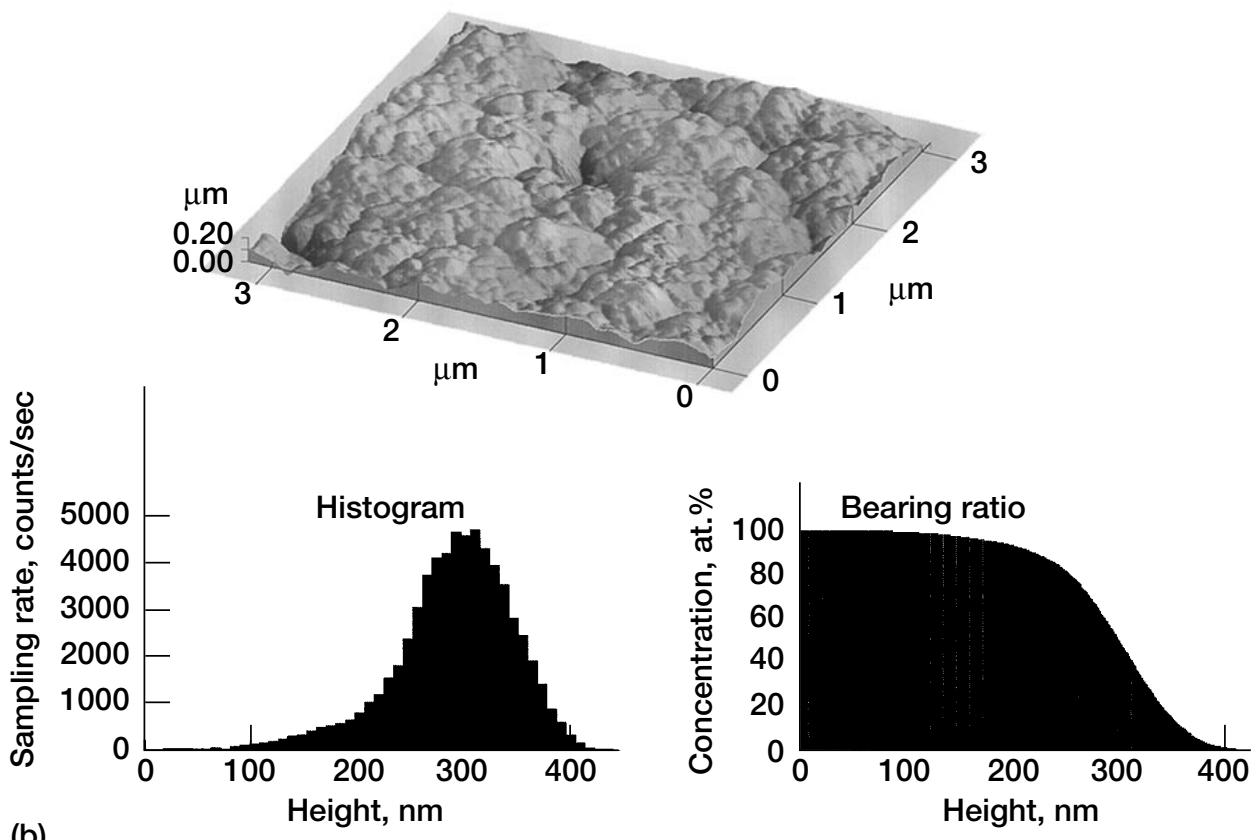

Figure 8.-Atomic force micrographs of carbon films deposited on mirror-polished silicon substrates. (a) Ion-beam-deposited, diamondlike carbon film. (b) Chemicalvapor-deposited, fine-grain diamond film. 
TABLE 3.- SELECTED ANALYTICAL TOOLS FOR STRUCTURE AND CRYSTALLOGRAPHY

\begin{tabular}{|c|c|c|c|c|}
\hline Technique & Main information & $\begin{array}{l}\text { Vertical resolution } \\
\text { (depth probed) } \\
\text { (typical)* }\end{array}$ & $\begin{array}{c}\text { Lateral resolution } \\
\text { (typical) }\end{array}$ & $\begin{array}{c}\text { Types of solid } \\
\text { specimen (typical) } \\
\text { and use } \\
\text { (popularity) }\end{array}$ \\
\hline $\begin{array}{l}\text { Low-energy electron } \\
\text { diffraction (LEED) }\end{array}$ & $\begin{array}{l}\text { Crystallography } \\
\text { Structure } \\
\text { Surface cleanliness } \\
\text { Surface disorder } \\
\text { Defects } \\
\text { Adsorbed gas } \\
\text { Oxide } \\
\text { Chemical reaction } \\
\text { Phase transition } \\
\text { Imaging }\end{array}$ & $\sim 0.4 \mathrm{~nm}$ & $\begin{array}{l}0.1 \mathrm{~mm}(\sim 10 \mu \mathrm{m} \\
\text { available })\end{array}$ & $\begin{array}{l}\text { Single crystal } \\
\text { (conductors, } \\
\text { semiconductors, } \\
\text { and insulators); } \\
\text { polycrystalline } \\
\text { specimens under } \\
\text { special } \\
\text { circumstances }\end{array}$ \\
\hline $\begin{array}{l}\text { Reflection high- } \\
\text { energy electron } \\
\text { diffraction } \\
\text { (RHEED) }\end{array}$ & $\begin{array}{l}\text { Crystallography } \\
\text { Structure } \\
\text { Surface cleanliness } \\
\text { Surface disorder } \\
\text { Defects } \\
\text { Surface roughness } \\
\text { Deposited film growth } \\
\text { Phase transition } \\
\text { Imaging }\end{array}$ & $2 \mathrm{~nm}$ to $10 \mathrm{~nm}$ & $200 \mu \mathrm{m}$ by $4 \mathrm{~mm}$ & $\begin{array}{l}\text { Single crystal } \\
\text { (conductors and } \\
\text { semiconductors); } \\
\text { polycrystalline } \\
\text { specimens under } \\
\text { special } \\
\text { circumstances }\end{array}$ \\
\hline $\begin{array}{l}\text { X-ray diffraction } \\
\text { (XRD) }\end{array}$ & $\begin{array}{l}\text { Crystalline phases } \\
\text { Strain state } \\
\text { Diffusion } \\
\text { Atomic spacings } \\
\text { Atomic arrangements } \\
\text { Crystallite orientation } \\
\text { Grain size } \\
\text { Defects } \\
\text { Film thickness }\end{array}$ & $\begin{array}{l}\text { A few } \\
\text { micrometers; } \\
\sim 5 \mathrm{~nm} \text { achievable } \\
\text { with laboratory- } \\
\text { based equipment }\end{array}$ & $\begin{array}{l}\text { Normally none; } \\
\text { although } \sim 10 \mu \mathrm{m} \\
\text { with microfocus }\end{array}$ & All \\
\hline
\end{tabular}

whereas XRD is a bulk method and provides bulk crystallographic and structural information. In standard form LEED and RHEED do not have much spatial resolution, beam spot sizes being a fraction of a millimeter. Microscopic modes using beam columns exist, however. Usually, XRD does not provide spatial resolution, but for special applications, resolution of greater than $\sim 10 \mu \mathrm{m}$ can be obtained with a microfocus source and a suitably thin film $(\sim 1 \mu \mathrm{m})$. One of the disadvantages of XRD, compared with electron diffraction, is the low intensity of diffracted $x$ rays, particularly for low-atomic number $(Z)$ materials. Typical intensities for electron diffraction are $\sim 10^{8}$ times larger than for XRD.

LEED is the best known and most widely used tool for investigating the crystallography of surfaces and overlayers or films adsorbed on surfaces. LEED is a standard tool in the analysis of single-crystal surfaces. LEED uses normal incidence, with electron energies between $10 \mathrm{eV}$ and $1000 \mathrm{eV}$, whereas RHEED uses grazing incidence and detection, with electron energies between $5 \mathrm{keV}$ and $50 \mathrm{keV}$. The diffraction pattern and the intensity distribution in the diffracted beams from rows of atoms can provide information on the positions of atoms in the surface and on the existence of various kinds of crystallographic disorder in the periodic arrangement of surface atoms. LEED gives information on surface order and cleanliness, surface atomic structure, adsorbed gas or oxide, phase transition in overlayers or surfaces, and chemical reactions of surfaces.

RHEED is the most similar to LEED, differing mainly by using grazing incidence instead of normal incidence. It is a surface-sensitive tool for probing surface structures and is ideally suited for the study of single-crystal surfaces. Although RHEED is a standard tool in the analysis of single-crystal surfaces, it can be used to study disordered real crystal surfaces and polycrystalline surfaces. When used to examine a real crystal surface, RHEED gives information on surface crystalline structure, crystallographic orientation, surface reconstruction (the rearrangement of surface atoms to minimize the surface energy), degree of surface disorder, and degree of surface roughness. 


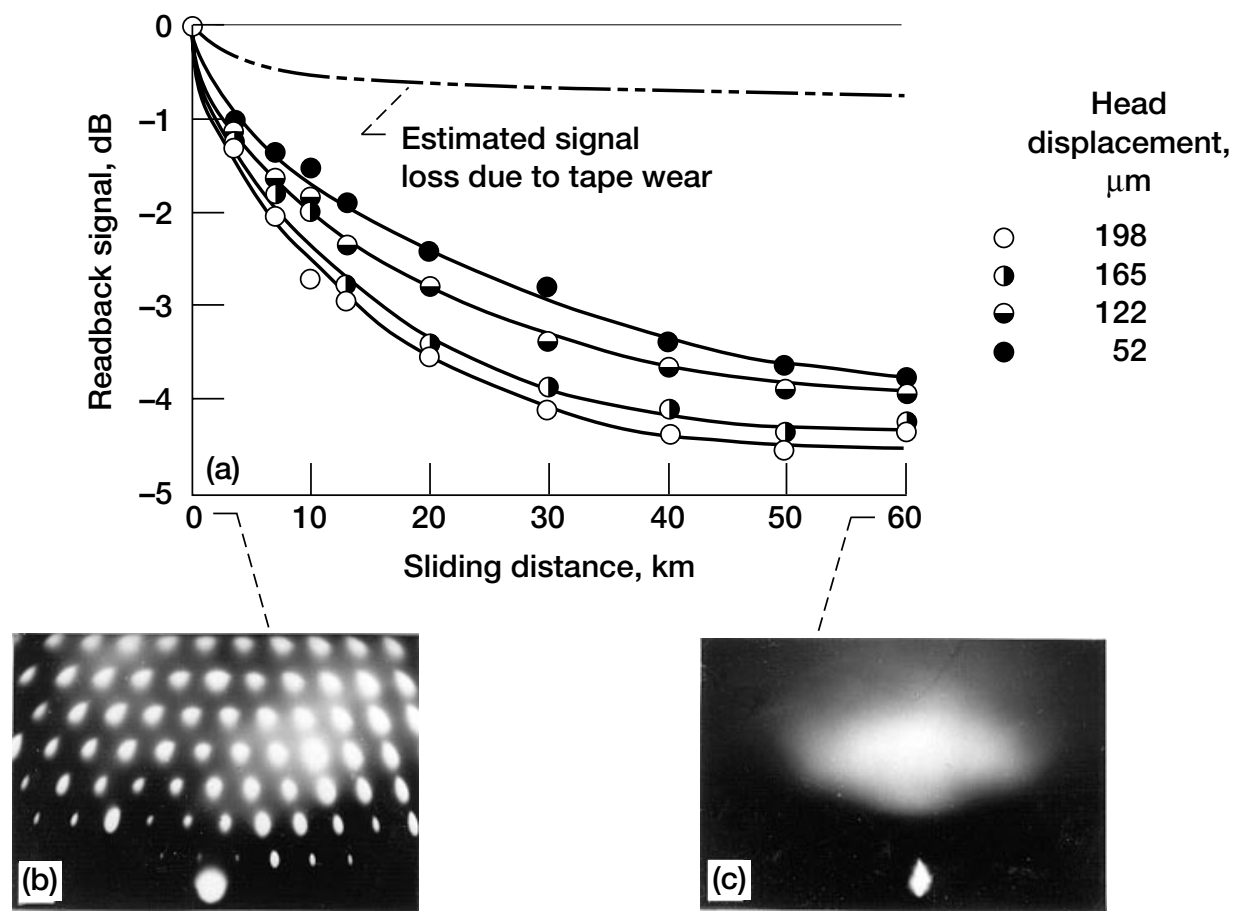

Figure 9.-Crystal structure and magnetic signal as function of sliding distance. Sliding materials, chemically etched Mn-Zn ferrite and magnetic tape. (a) Readback signal. Electron diffraction patterns of (b) highly strained single-crystal structure before sliding and (c) nearly amorphous structure after $60 \mathrm{~km}$ of sliding.

Figure 9 shows classic examples of crystal structural damage in manganese-zinc (Mn-Zn) ferrite as verified by RHEED and the effect of the damage on its magnetic properties [31]. On a magnetic tape recorder the sliding of the magnetic tape abrades the Mn-Zn ferrite head and scratches its surface. Considerable surficial plastic flow occurs on the ferrite surface, and the large number of defects produced can drastically change the crystalline state of the ferrite head and produce a worked layer on its surface. The worked layer decreases readback signal amplitude and degrades the signal obtained in short-wavelength recording. Figure 9(a) shows the readback signals from a new, chemically etched single-crystal Mn-Zn ferrite magnetic head in sliding contact with a magnetic tape as a function of sliding distance. Figures 9(b) and (c) show the electron diffraction patterns taken from the magnetic head surface before and after sliding. Clearly, the sliding action changed the crystalline state of the magnetic head's surficial layer from a single-crystal structure to a nearly amorphous one. That crystallographic change in $\mathrm{Mn}-\mathrm{Zn}$ ferrite is a critical factor in the readback signal losses shown in fig. 9(a).

When RHEED is used to study film growth on crystalline surfaces, it gives information on the nucleation, growth, and growth rate of epitaxial films (e.g., molecular beam epitaxy (MBE); structural changes as a function of temperature or time; the deposited film growth mode (i.e., whether it grows layer by layer or as three-dimensional crystallites); the crystalline structure; and the film's orientation with respect to the substrate).

$\mathrm{XRD}$ is the classical, most widely used tool for general crystalline material characterization. With the use of high-brightness $\mathrm{X}$-ray sources the surface structure also can be determined by grazing incidence methods. XRD offers unparalleled accuracy in measuring atomic spacings. It identifies crystalline phases present in materials and measures the structural properties of these phases, such as strain state, crystallite size, grain size, epitaxy, phase formation and composition, preferred orientation, diffusion, and defect structure. XRD is also used to determine the thickness of thin films and multiple layers and the atomic arrangements in amorphous materials including polymers and at interfaces. 


\section{Concluding Remarks}

Surface modifications, thin films, and multiple-layered coatings designed for engineering materials will become more important in the future. To understand the benefits that surface engineering techniques provide, and ultimately to devise better ones, researchers must study the chemical, physical, and structural characteristics of material surfaces obtained by a given process. Therefore, the use of surface analyses and surface characterization tools will grow in importance.

A wide variety of analytical tools are available for diagnosing the chemical, physical, and structural characteristics of surfaces. Each surface analysis technique and its tool provides unique chemical, physical, and structural information. Each technique has its strengths and weaknesses. Therefore, no single tool can provide the answers to all problems. In many cases, multiple tools must be used to reach an answer. It should be possible to coordinate the different pieces of information provided by these surface analyses and tools into a coherent, self-consistent description of surfaces and their bulk characteristics.

\section{References}

1. Miyoshi, K., 2001, Solid Lubrication: Fundamentals and Applications, Marcel Dekker, New York.

2. Miyoshi, K., and Chung, Y-W., eds., 1993, Surface Diagnostics in Tribology: Fundamental Principles and Applications, World Scientific Publishing Co., River Edge, NJ.

3. Burnnell-Gray, J.S., and Datta, P.K., eds., 1996, Surface Engineering Casebook, Solutions to Corrosion and Wear-Related Failures, Woodhead Publishing Limited, Cambridge, UK.

4. Bunshah B., et al, eds., 1982, Deposition Technologies for Films and Coatings: Developments and Applications, Noyes Publications, Park Ridge, NJ.

5. Mort, J., and Jansen, F., eds., 1988, Plasma Deposited Thin Films, CRC Press, Inc., Boca Raton, FL.

6. Holmberg, K., and Matthews, A., 1994, Coatings Tribology: Properties, Techniques, and Applications in Surface Engineering, Tribology Series 28, D. Dowson, ed., Elsevier, Amsterdam.

7. Kumar, A. , Chung, Y-W., Moore, J.J., and Smugeresky, J.E., eds., 1999, Surface Engineering: Science and Technology 1, The Minerals, Metals, \& Materials Society, Warrendale, PA.

8. Amelinckx, S., Gevers, R., Remaut, G., and Landuyt, J.V., eds., 1970, Modern Diffraction and Imaging Techniques in Materials Science, North-Holland Publishing Co., Amsterdam-London.

9. Briggs, D., Seah, M.P., and Grant, J. T., eds., 1988, Surface and Interface Analysis, ECASIA 87, Proceedings of the European Conference on Applications of Surface and Interface Analysis, SIANDQ, Vol. 12, Nos. 1-12, John Wiley \& Sons, New York.

10. Brundle, C.R., Evans, C.A., Jr., and Wilson, S., eds., 1992, Encyclopedia of Materials Characterization, Butterworth-Heinemann, Stoneham, MA.

11. Brewis, D.M., ed., 1982, Surface Analysis and Pretreatment of Plastics and Metals, Macmillan, New York.

12. Miyoshi, K., and Buckley, D.H., 1979, "Friction, Deformation, and Fracture of Single-Crystal Silicon Carbide," ASLE Transactions, 22, pp. 79-90.

13. Norton, J.T., and Cameron, G.T., Sr., eds., 1986, "Electron Optical and X-ray Instrumentation for Research, Product Assurance and Quality Control," Amray Technical Bulletins, Vol. 2, No. 1, Amray, Inc., Bedford, MA.

14. Chung, Y-W., and Cheng, H.S., eds., 1991, Advances in Engineering Tribology, STLE SP-31, Society of Tribologists and Lubrication Engineers, Park Ridge, IL.

15. Chung, Y-W., Homola, A.M., and Street, G.B., eds., 1992, Surface Science Investigations in Tribology: Experimental Approaches, ACS Symposium Series 485, American Chemical Society, Washington, DC. 
16. Buckley, D.H., 1981, Surface Effects in Adhesion, Friction, Wear, and Lubrication, Tribology Series 5, Elsevier, Amsterdam.

17. Quinn, T.F.J., 1991, Physical Analysis for Tribology, Cambridge University Press, Cambridge, UK.

18. Glaeser, W.A., ed., 1993, Characterization of Tribological Materials, Butterworth-Heinemann, Stoneham, MA.

19. Briggs, D., and Seah, M.P., 1983, Practical Surface Analysis: By Auger and X-Ray Photo-Electron Spectroscopy, Vol. 1, John Wiley \& Sons, New York.

20. Tsukizoe, T., 1970, Precision Metrology, Yokkendo Publishing, Tokyo, Japan, pp. 180-199.

21. Williamson, J.B.P., 1984, "The Shape of Surfaces," CRC Handbook of Lubrication, E.R. Booser, ed., CRC Press Inc., Boca Raton, FL, Vol. II, pp. 3-16.

22. Studt, T., editor-in-chief, 2001, "Thin-Film Survey, Vacuum/Thin Films," Research \& Development Magazine, 43, 9, p. 84.

23. Miyoshi, K., 1991, "Uses of Auger and X-ray Photoelectron Spectroscopy in the Study of Adhesion and Friction," Advances in Engineering Tribology, STLE SP-31, Y-W. Chung and H.S. Cheng, eds. Society of Tribologists and Lubrication Engineers, Park Ridge, IL, pp. 3-12.

24. Miyoshi, K., and Buckley, D.H., 1983, "Tribological Properties and Surface Chemistry of Silicon Carbide at Temperatures to $1500{ }^{\circ} \mathrm{C}, "$ ASLE Transactions, 26, 1, pp. 53-63.

25. Singer, I.L., 1991, "Solid Lubrication Processes," Fundamentals of Friction: Macroscopic and Microscopic Processes, I.L. Singer and H.M. Pollock, eds., Kluwer Academic Publishers, Dordrecht, pp. 237-261.

26. Miyoshi, K., 1999, “Aerospace Mechanisms and Tribology Technology, Case Study,” Tribology International, 32, pp. 673-685.

27. Caber, P.J., Martinek, S.J., and Niemann, R.J., 1993, “A New Interferometric Profiler for Smooth and Rough Surfaces," WYKO Technical Bulletin 1993-27A, WYKO, Tucson, AZ, pp. 1-14.

28. Howland, R.S., Okagaki, J., and Mitobe, L., 1993, "How to Buy a Scanning Probe Microscope," Park Scientific Instruments, Sunnyvale, CA.

29. Miyoshi, K., 2001, "Characterization of Solid Surfaces," Solid Lubrication: Fundamentals and Applications, Marcel Dekker, New York, pp. 23-97.

30. Miyoshi, K., and Wu, R.L.C., 2001, "Measurements and Diagnostics of Diamond Films and Coatings," Measurement, 29, pp. 113-126.

31. Miyoshi, K., Buckley, D.H., and Tanaka, K., 1986, Effect of Crystallographical and Geometrical Changes of a Ferrite Head on Magnetic Signals During the Sliding Process With Magnetic Tape, ASLE Special Publication SP-21, pp. 50-56. 


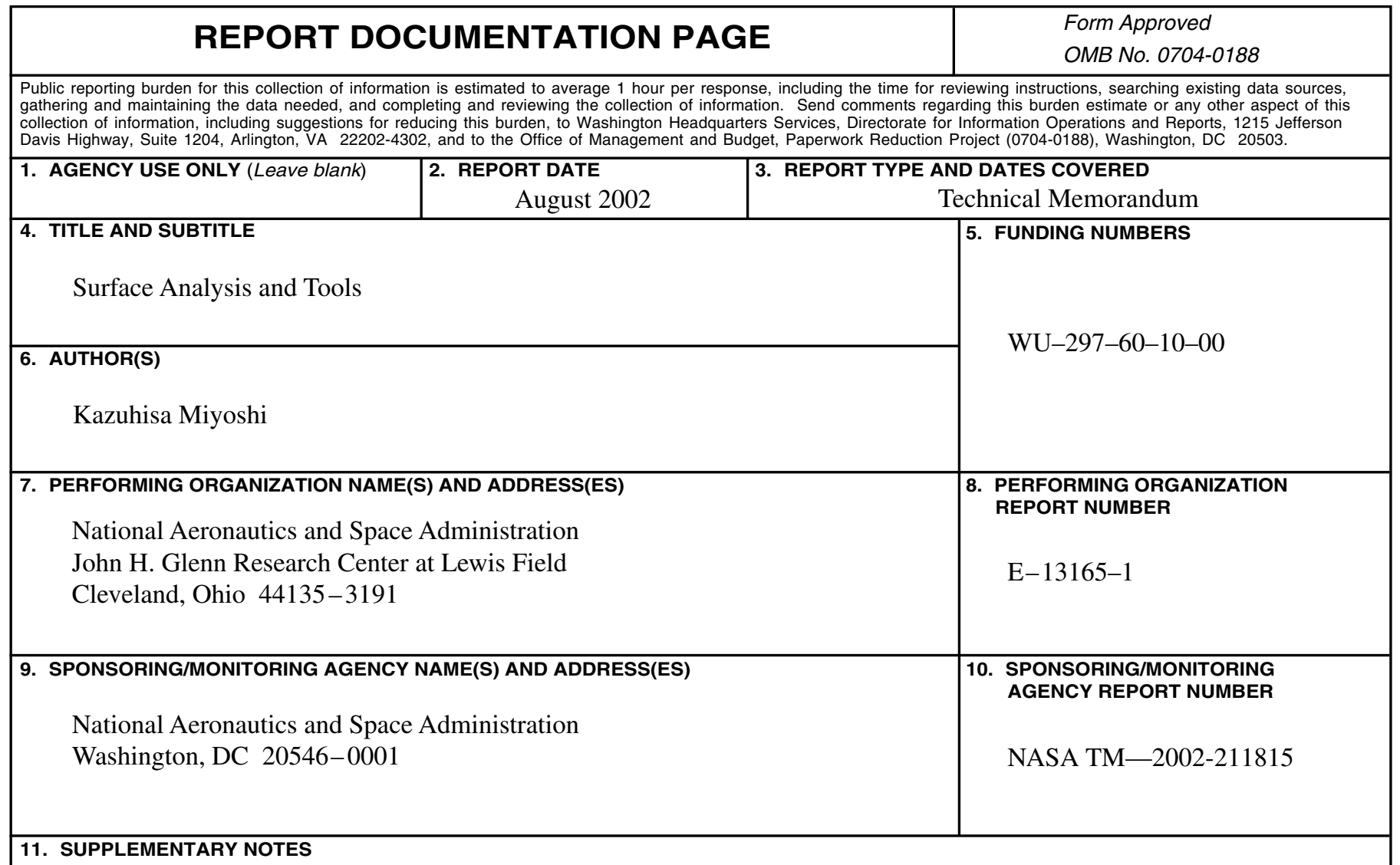

Responsible person, Kazuhisa Miyoshi, organization code 5160, 216-433-6078.

12a. DISTRIBUTION/AVAILABILITY STATEMENT

12b. DISTRIBUTION CODE

Unclassified - Unlimited

Subject Category: 27

Distribution: Nonstandard

Available electronically at http://gltrs.grc.nasa.gov

This publication is available from the NASA Center for AeroSpace Information, 301-621-0390.

13. ABSTRACT (Maximum 200 words)

This article is a chapter of the book entitled, "Tribology of Mechanical Systems," to be published by ASME Press, New York, NY. It describes selected analytical techniques, which are being used in understanding phenomena and mechanisms of oxidation, adhesion, bonding, friction, erosion, abrasion, and wear, and in defining the problems.

The primary emphasis is on microanalytical approaches to engineering surfaces.

\begin{tabular}{|c|c|c|c|}
\hline \multirow{2}{*}{\multicolumn{3}{|c|}{$\begin{aligned} \text { 14. } & \text { SUBJECT TERMS } \\
& \text { Surface properties }\end{aligned}$}} & \multirow{3}{*}{$\begin{array}{l}\text { 15. NUMBER OF PAGES } \\
24 \\
\text { 16. PRICE CODE } \\
\text { 20. LIMITATION OF ABSTRACT }\end{array}$} \\
\hline & & & \\
\hline $\begin{array}{l}\text { 17. SECURITY CLASSIFICATION } \\
\text { OF REPORT } \\
\text { Unclassified }\end{array}$ & $\begin{array}{l}\text { 18. SECURITY CLASSIFICATION } \\
\text { OF THIS PAGE } \\
\text { Unclassified }\end{array}$ & $\begin{array}{l}\text { 19. SECURITY CLASSIFICATION } \\
\text { OF ABSTRACT } \\
\text { Unclassified }\end{array}$ & \\
\hline SN 7540-01-280-5500 & & & $\begin{array}{l}\text { andard Form } 298 \text { (Rev. 2-89) } \\
\text { scribed by ANSI Std. Z39-18 } \\
3-102\end{array}$ \\
\hline
\end{tabular}

